Jurnal

Kardiologi Indonesia

J Kardiol Indones. 2013;34:280-8

ISSN 0126/3773

\title{
MRI Kardiak untuk Gagal Jantung akibat Kardiomiopati
}

\author{
Sony Hilal Wicaksono, Donny Setyawan Syamsul, Citra Primasari, Aprivita Gayatri, \\ Asmoko Resta Permana
}

$\mathrm{K}$ ardiomiopati (KM) merupakan penyakit miokardium dengan karakteristik gangguan yang nyata pada morfologi, elektrofisiologi dan fungsi jantung. ${ }^{1}$ Definisi lain menyebutkan bahwa KM adalah kelainan miokardium dengan abnormalitas pada struktur dan fungsi otot jantung, tanpa adanya penyakit jantung koroner, hipertensi, penyakit jantung katup ataupun kongenital yang melatarbelakanginya. Kardiomiopati dapat diklasifikasikan dalam dua kelompok besar yaitu KM primer dan KM sekunder. KM primer merupakankardiomiopati yang etiologinya tidak diketahui sedangkan kardiomiopati sekunder merupakan kardiomiopati yang diketahui etiologinya atau terkait kelainan sistemik maupun kelainan miokardium khusus lainnya. ${ }^{2}$

Penegakan diagnosis KM dan klasifikasinya didasarkan pada penilaian morfologi dan fungsi jantung. ${ }^{3}$ Penetapan diagnosis KM primer dilakukan dengan mengeksklusi penyakit/kelainan jantung yang lain. ${ }^{4}$ Seiring pengamatan klinis, perbedaan antara KM primer dan sekunder akan menjadi semakin jelas, karena ditemukannya etiologi pada kasus yang sebelumnya dianggap merupakan kelainan idiopatik. $^{2}$

Klasifikasi KM lainnya yang diajukan kemudian

Tabel 1. Klasifikasi KM dari American heart Association (AHA) tahun $2006 .{ }^{5}$

\begin{tabular}{|c|c|}
\hline KM Primer & KM Sekunder \\
\hline $\begin{array}{l}\text { - Genetik (KM hipertopi/ Hypertropic Cardiomyopathy/ } \\
\text { HCM; abnormalitas konduksi; sindroma QT meman- } \\
\text { jang; sindroma brugada } \\
\text { Mixed/Campuran (KM dilatasi/ Dilated Cardiomyopathy/ } \\
\text { DCM; KM restriktif/Restrictive Cardiomyopathy/ } \\
\text { RCM) } \\
\text { Acquired/didapat (Miokarditis inflamasi; peripartum; } \\
\text { KM Takotsubo/broken heart syndrome) }\end{array}$ & 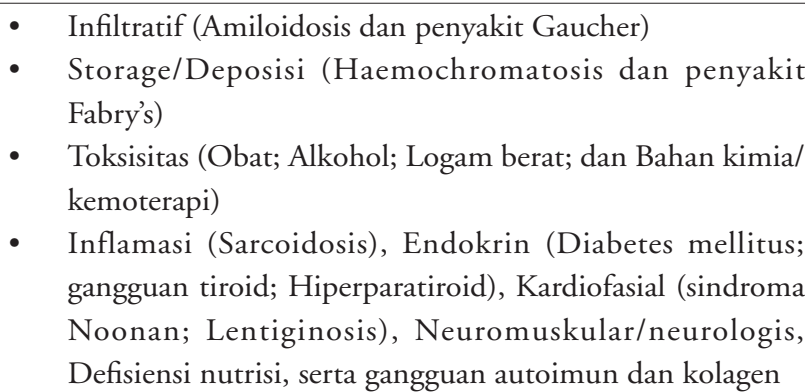 \\
\hline
\end{tabular}

Alamat Korespondensi

dr. Sony Hilal Wicaksono, SpJP. Departemen Kardiologi dan Kedokteran Vaskular FKUI dan Pusat Jantung Nasional Harapan Kita, Jakarta. E-mail: Sonym4n@gmail.com telah beralih dari konsep yang berdasar diagnosa dan lebih terfokus pada morfologi dan fungsi jantung. Hal ini sederhana namun sangat mendasar dari kesepakatan yang telah ada, memiliki arti bahwa perbedaan antara KM dan 
penyakit miokardium khusus telah ditinggalkan (dengan pengecualian pada hipertensi, penyakit jantung koroner, penyakit jantung katup dan anomali jantung kongenital). Pembagian KM menjadi familial dan non-familial dibuat untuk meningkatkan kewaspadaan terhadap kelainan genetik sebagai penyebab disfungsi miokardium, serta membangun kerangka berpikir logis yang menjadi landasan penelitian selanjutnya di masa mendatang. ${ }^{2}$
Meskipun pemeriksaan ekokardiografi merupakan modalitas yang vital dan lebih mudah diakses dibanding modalitas yang lebih modern namun kualitas gambar dan perhitungan fungsi sistolik ventrikel kiri, kemampuannya menghasilkan tekstur jaringan yang lebih detail untuk membedakan etiologi dari gagal jantung masih terbatas. Pemeriksaan CMR dalam hal ini merupakan standar baku emas untuk penilaian

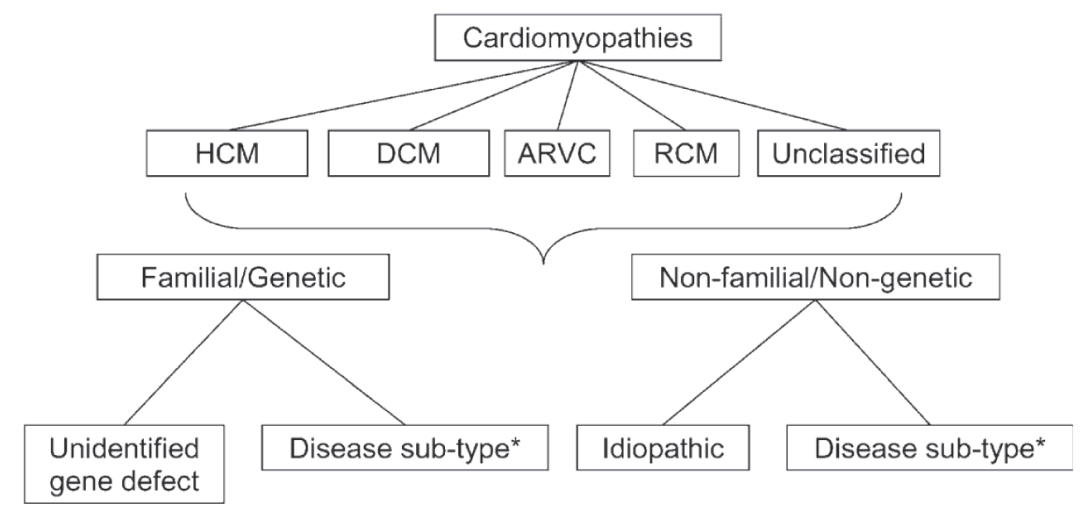

Gambar 1. Klasifikasi KM berdasarkan fenotip morfologi dan fungsi khusus. Keterangan : ARVC, Arrhythmogenic Right Ventricular Cardiomyopathy; DCM, Dilated Cardiomyopathy; HCM,Hypertrophic Cardiomyopathy; RCM, Restrictive Cardiomyopathy. ${ }^{2}$

Penentuan etiologi yang tepat pada KM sangat penting karena etiologi berhubungan langsung dengan tatalaksana dan prognosis pasien. Namun penentuan ini dapat menjadi sulit dengan menggunakan teknik pencitraan yang ada seperti ekokardiografi dan pencitraan nuklir (resolusi kontras dan ruang/bidang evaluasi yang kurang serta evaluasi jaringan yang terbatas), atau koroangiografi kateter (terbatas dalam menilai lumen ruang jantung, dengan gambaran tidak langsung perubahan miokardium), bahkan mungkin diperlukan gabungan dari beberapa pemeriksaan tersebut untuk saling melengkapi. Biopsi endomiokardium sebagai standar baku emas bahkan masih memiliki keterbatasan berupa resiko kesalahan sampel dan sensitifitas yang rendah. Alternatif baru berupa pencitraan Cardiovascular Magnetic Resonance (CMR) merupakan modalitas pencitraan noninvasif terbaru, yang secara in vivo terbukti dapat menghasilkan gambar dengan resolusi tinggi pada bidang jantung manapun yang diinginkan tanpa radiasi. Cardivascular Magnetic Resonance juga memiliki beberapa teknik pemeriksaan yang dapat digunakan secara terpisah atau terkombinasi selama pemeriksaan pada pasien. ${ }^{1,6}$ massa ventrikel kiri, fungsi sistolik dan penilaian fibrosis miokard. Pemeriksaan CMR juga mempunyai kelebihan dalam menyajikan gambar dari tiga bidang dimensi, sehingga didapatkan penilaian dari fungsi dan volum ventrikel kiri dan ventrikel kanan, fraksi ejeksi dan massa ventrikel. Modalitas ini juga dapat menilai perfusi miokard dan mengimplementasikan teknik pencitraan lain seperti delayed hyperenhancement
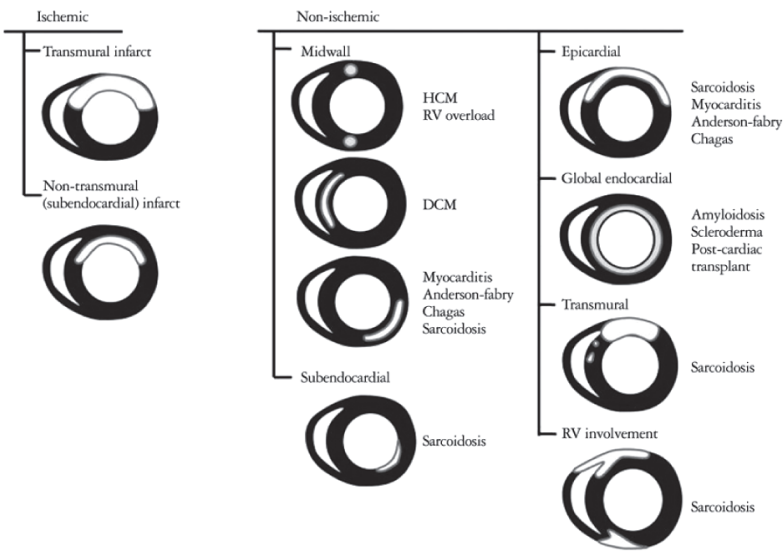

Gambar 2. Pola LGE pada CMR yang membedakan berbagai tipe kardiomiopati dengan penyakit jantung koroner. ${ }^{7}$ 
cardiovascular magnetic resonance (DHE-CMR), T1-weighed, T2-weighed, dan teknik pencitraan fat suppresion untuk menilai fibrosis miokard dan edema miokard. ${ }^{7}$

Pencitraan DHE-CMR sendiri memungkinkan untuk mengidentifikasi fibrosis miokard baik itu disebabkan oleh gangguan iskemik maupun yang non iskemik. Pada gagal jantung karena iskemik akan ditemukan pola delayed hyperenhancement pada seluruh ketebalan otot miokard (transmural) atau hanya subendokardium saja (non-transmural). Pemeriksaan ini juga mampu membedakan antara tipetipe kardiomiopati berdasarkan pola unik dari fibrosis yang terdapat pada miokard (gambar 2). ${ }^{7}$

Tabel 2. Aplikasi dan perbandingan berbagai teknik pencitraan yang dapat dilakukan dalam diagnosis penyakit kardiovaskular. $^{8}$

\begin{tabular}{|c|c|c|c|c|c|c|c|}
\hline & & Echo & CMR & Cath & SPECT & MDCT & PET \\
\hline \multicolumn{8}{|l|}{ Etiologi } \\
\hline \multirow[t]{4}{*}{ CAD } & Iskemia & +++ & +++ & - & +++ & - & +++ \\
\hline & Hibernasi & +++ & +++ & - & +++ & - & +++ \\
\hline & Skar & ++ & +++ & - & ++ & - & ++ \\
\hline & Anatomi koroner & - & - & +++ & - & +++ & - \\
\hline \multirow[t]{2}{*}{ Valvular } & Stenosis & +++ & + & +++ & - & ++ & - \\
\hline & Regurgitasi & +++ & ++ & ++ & - & - & - \\
\hline Miokarditis & & + & +++ & +++ & - & - & - \\
\hline Sarkoidosis & & + & +++ & ++ & - & - & ++ \\
\hline \multirow[t]{2}{*}{$\mathrm{HCM}$} & HCM & +++ & ++ & ++ & - & - & - \\
\hline & Amiloidosis & ++ & +++ & +++ & - & - & - \\
\hline \multirow[t]{4}{*}{ DCM } & Miokarditis & + & +++ & +++ & - & - & - \\
\hline & Sindroma Eosinofilia & + & +++ & +++ & - & - & - \\
\hline & Hemokromositoma & + & +++ & - & - & - & - \\
\hline & Talasemia Besi & + & +++ & - & - & - & - \\
\hline ARVC & & ++ & +++ & +++ & - & + & - \\
\hline \multirow{4}{*}{$\mathrm{RCM}$} & Pericarditis & ++ & ++ & ++ & - & ++ & - \\
\hline & Amiloidosis & ++ & +++ & +++ & - & - & - \\
\hline & $\begin{array}{c}\text { Fibrosis Endomiokar- } \\
\text { dium }\end{array}$ & + & +++ & +++ & - & - & - \\
\hline & Anderson-Fabry & + & + & - & - & - & - \\
\hline $\begin{array}{l}\text { KM yang } \\
\text { tidak terklas- } \\
\text { ifikasi }\end{array}$ & KM Takotsubo & ++ & ++ & +++ & - & - & - \\
\hline \multicolumn{8}{|c|}{ Keuntungan utama } \\
\hline & & $\begin{array}{l}\text { Availabilitas } \\
\text { tinggi, Porta- } \\
\text { bel, Non- } \\
\text { radiasi, relatif } \\
\text { murah } \\
\end{array}$ & $\begin{array}{c}\text { Kualitas } \\
\text { gambar baik, } \\
\text { Non-radiasi }\end{array}$ & $\begin{array}{l}\text { Availabilitas } \\
\text { baik }\end{array}$ & $\begin{array}{l}\text { Availabilitas } \\
\text { baik }\end{array}$ & $\begin{array}{c}\text { Availabilitas } \\
\text { beralasan, } \\
\text { Kualitas } \\
\text { gambar } \\
\text { tinggi }\end{array}$ & $\begin{array}{c}\text { Availabilitas } \\
\text { terbatas, } \\
\text { Kualitas } \\
\text { gambar baik }\end{array}$ \\
\hline \multicolumn{8}{|c|}{ Kerugian utama } \\
\hline & & $\begin{array}{l}\text { Perlu echo } \\
\text { window }\end{array}$ & $\begin{array}{c}\text { Availabilitas } \\
\text { terbatas, Ada } \\
\text { kontraindikasi, } \\
\text { Analisa fungsi } \\
\text { dan kualitas } \\
\text { gambar terba- } \\
\text { tas bila aritmia }\end{array}$ & $\begin{array}{l}\text { Inavsif } \\
\text { radiasi }\end{array}$ & Radiasi & $\begin{array}{c}\text { Radiasi, } \\
\text { Kualitas } \\
\text { gambar } \\
\text { terbatas bila } \\
\text { aritmia }\end{array}$ & $\begin{array}{c}\text { Radiasi, } \\
\text { Availabilitas } \\
\text { terbatas }\end{array}$ \\
\hline
\end{tabular}


Berdasarkan tabel 2, modalitas pencitraan noninvasif yang paling baik dalam evaluasi dan penilaian KM adalah dengan Cardiovascular Magnetic Resonance (CMR). Berbagai teknik pada CMR yang dapat digunakan pada kardiomiopati, antara lain ; cine-CMR untuk penilaian morfologi dan fungsi jantung, firstpass contrast-enhanced perfusion-CMR untuk penilaian perfusi miokardium, dan Delayed contrast Enhanced $C M R(\mathrm{DE}-\mathrm{CMR})$ untuk identifikasi karakteristik jaringan secara non-invasif. ${ }^{6}$ Protokol pencitraan CMR untuk pemeriksaan non-iskemik kardiomiopati pada ventrikel kiri adalah sebagai berikut ${ }^{9}$ :

1. Penilaian struktur dan fungsi ventrikel kiri.

2. Pemeriksaan gambaran T2-weighted pada kondisi akut yang kemungkinan terdapat edema ataupun nekrosis miokardium.

a. Penggunaan body coil ataupun functional surface coil sebagai algoritma untuk koreksi.

b. Pengambilan gambar saat pasien menahan nafas dan pencitraan dengan segmented fast spin echo (double inversion recovery).

c. Melakukan pencitraan sebelum pemberian kontras

d. Pemilihan segmen pencitraan berdasarkan hasil pemeriksaan Cine.

e. Penyesuaian readout saat mid-diastole

f. Ketebalan segmen pencitraan minimal $10 \mathrm{~mm}$.

g. Ketebalan segmen pencitraan dengan teknik dark blood harus lebih besar daripada base-apex motion anulus mitral.

3. Pemeriksaan Late Gadolinium Enhancement.

- Analisis : penilaian pola perubahan miokardium, dimana pada beberapa kardiomiopati noniskemik mempunyai predileksi pembentukan scar dengan tampilan khusus.

4. Optional : Pencitraan dengan adenosine stress-rest perfusion ataupun dengan high dose dobutamine stress functional imaging untuk mengetahui ada tidaknya iskemia, karena iskemiadapat ditemui pada mixed kardiomiopati.

5. Pencitraan outflow tract ventrikel kiri pada hypertrophic cardiomyopathies untuk menilai adanya turbulensi, diskinetik sistolik ataupun pengukuran gradien aliran.

\section{Kardiomiopati Dilatasi/Dilated Cardiomyopathy (DCM)}

Abnormalitas anatomi pada DCM dapat dengan jelas ditunjukkan pada ekokardiografi atau CMR berupa pembesaran kedua atrium serta peningkatan ukuran ventrikel kiri dan kanan (gambar 2). Dapat juga dijumpai adanya efusi di perikardium atau pleura, dilatasi vena kava superior atau inferior ataupun trombus pada ventrikel. Abnormalitas fungsional ditunjukkan berupa abnormalitas pergerakan dinding segmental atau disfungsi global. Regurgitasi mitral atau trikuspid juga dapat dilihat dengan baik pada cine-CMR. ${ }^{1}$

McCrohon dkk pada penelitian dengan DE-CMR menyimpulkan bahwa pola enhancement miokardium pada pemeriksaan CMR dapat membedakan disfungsi ventrikel kiri terkait DCM atau terkait PJK. Mayoritas pasien DCM tidak menunjukkan adanya ambilan kontras sedangkan pada sebagian pasien late enhancement terlihat di mid-miokardium pada pola non-koroner, yang jelas dapat dibedakan dengan PJK. CMR juga berguna dalam evaluasi efek terapi pada pasien. ${ }^{1,3}$ Etiologi pada DCM sering tidak diketahui, namun mungkin dihasilkan dari proses miopati genetik atau miokarditis sebelumnya, dan hal ini terkait dengan prognosis. ${ }^{3}$

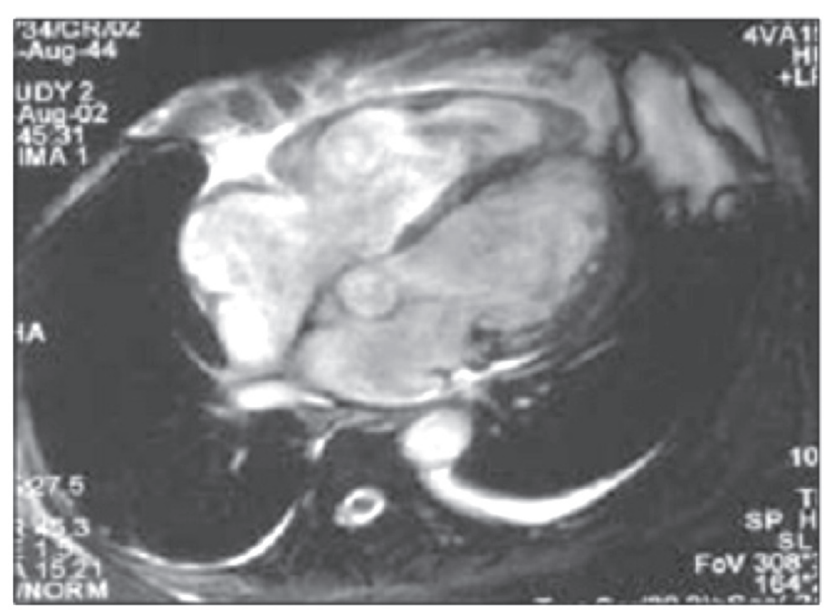

Gambar 2. Diastolic 4-CH SSFP fase diastolik menunjukkan dilatasi pada semua ruang jantung, penipisan dinding ventrikel, efusi perikard dan pleura minimal. ${ }^{1}$

\section{Kardiomiopati hipertrofi/Hypertrophic cardiomyopathy/HCM}

Diagnosis klinis HCM secara konvensional dibuat dengan pencitraan yaitu dengan pemeriksaan ekokardiografi 2-dimensi (2D) ataupun alternatif yang lebih baik dengan pemeriksaan CMR. Diagnosis morfologi dilakukan berdasarkan adanya hiperrtrofi 


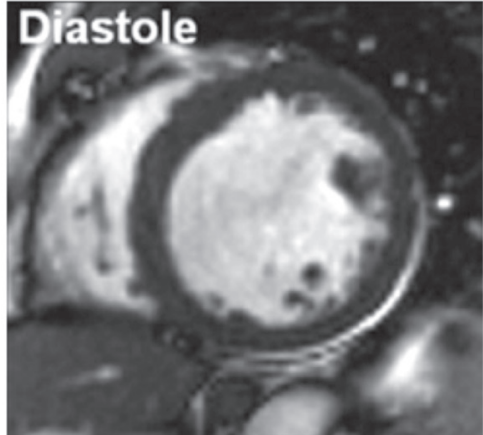

(A)

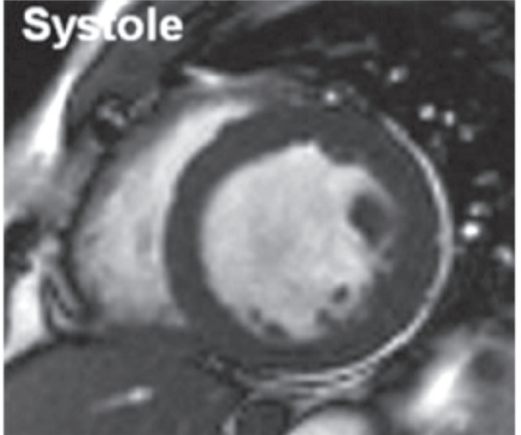

(B)

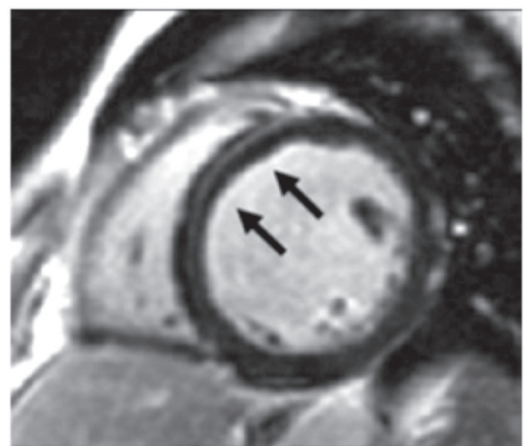

(C)

Gambar 3. (A-C) Dilatasi ruang ventrikel kiri dan fungsi sistolik yang rendah. LGE menunjukkan adanya mid-wall hyperenhancement (panah). Gambar ini merupakan cine SSFP saat diastolik (A) dan sistolik (B) serta inversion recovery setelah bolus gadolinium $(\mathrm{C}){ }^{3}$

dan non dilatasi ventrikel kiri, tanpa adanya penyakit jantung/sistemik lain yang mendasari timbulnya hipertrofi pada pasien (biasanya $\geq 15 \mathrm{~mm}$ pada dewasa atau relatif sesuai luas permukaan tubuh pada anak). ${ }^{10} \mathrm{HCM}$ merupakan penyakit jantung genetik yang merupakan penyebab tersering kematian mendadak pada usia muda. ${ }^{11}$

HCM merupakan kondisi hipertrofi miokardium yang simetris (gambar $4 \mathrm{~A}$ ) ataupun asimetris. Pada ekhokardiografi, hipertrofi yang asimetris pada

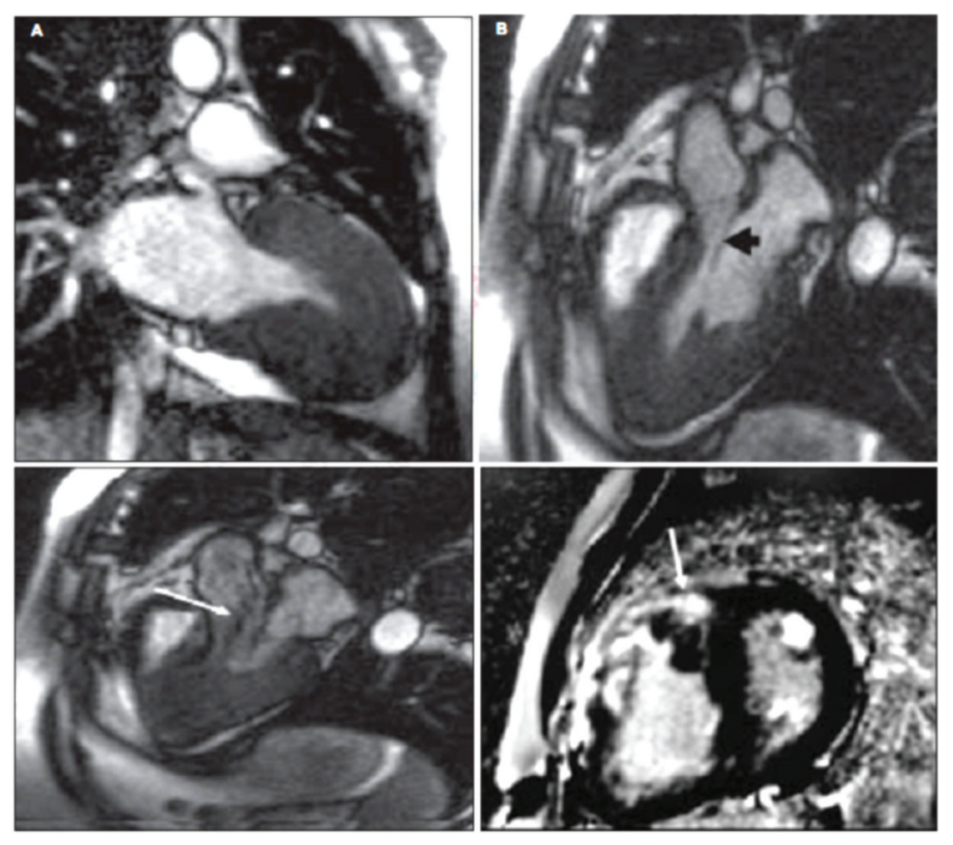

Gambar 4. (A-D)Gambar VLA SSFP sistolik pada HCM (A) menunjukkan penyempitan signifikan rongga ventrikel kiri akibat hipertrofi miokardium difus pada pasien dengan HCM simetris.Gambar 3-CH SSFP diastolik (B) menunjukkan penyempitan daerah LVOT dibawah pangkal aorta, dibatasi dengan daun anterior katup mitral (panah) dan septum interventrikel bagian atas. Gambar SSFP sistolik (C) dari seri gambar yang sama menunjukkan tanda kosong (panah) yang dihasilkan velositas yang tinggi dari jet turbulensi melalui LVOT akibat obstruksi. (D) DE-CMR, gambar aksis pendek menunjukkan enhancementpada dinding antero-lateral dari ventrikel kiri, pada miokardium ventrikel kanan dan pada titik insersi ventrikel kanan septum (panah). ${ }^{1}$ 
apeks ventrikel kiri mungkin tidak terevaluasi dengan jelas, namun CMR dapat mengidentifikasi dengan tepat lokasi dan luas hipertrofi, termasuk pada apeks ventrikel kiri. Fungsi jantung dan aliran dinamik outflowpada kasus Hypertrophic Obstructive Cardiomyopathy (HOCM), termasuk Systolic Anterior Motion(SAM) katup mitral, dapat dilihat dengan baik pada cine-CMR (gambar 4B dan 4C). Perhitungan planimetri yang tepat dari daerah LVOT selama sistolik juga dapat dinilai. ${ }^{1}$ CMR dibandingkan dengan ekokardiografi memberikan visualisasi yang lebih baik dan potensial dalam menilai jaringan parut. ${ }^{12}$

DE-CMR menunjukkan pola ambilan kontras pada daerah fibrosis yang membedakan dengan KM iskemik, yang tidak melibatkan subendokardium. Hal ini biasanya terlihat pada daerah hipertrofi atau pada titik insersi ventrikel kanan pada septum (gambar 4D). Pasien yang menunjukkan adanya hyperenhancementmeningkatkan risiko kematian jantung mendadak. Bello, dkk,smenunjukkan pasien dengan late enhancementbiasanya tidak berespon dengan terapi gagal jantung, namun mungkin memiliki keuntungan dengan pemasangan defibrilator. CMR juga digunakan untuk evaluasi anatomi dan fungsi pasca tindakan septektomi bedah maupun farmakologi. CMR berguna untuk monitor probands relatif, merupakan teknik yang dipilih untuk diagnosis dan evaluasi semua tipe HCM. Penilaian massa total ventrikel kiri dan perkembangannya dalam waktu tertentu dapat dievaluasi dengan lebih baik dibandingkan dengan ekokardiografi. ${ }^{1}$

\section{Kardiomiopati restriktif/Restrictive Cardiomyopathy/RCM}

Definisi WHO untuk RCM merupakan suatu penyakit miokardium dengan pengisian restriktif dan berkurangnya volume diastolik pada salah satu maupun kedua ventrikel dengan penebalan dinding ventrikel dan fungsi sistolik mendekati normal. Kelainan ini hampir 5\% dari semua sebab primer kelainan miokardium. ${ }^{1}$

RCM dididentifikasi pada CMR dengan ukuran ventrikel kiri yang normal atau gangguan fungsi sistolik ringan, gangguan fungsi diastolik berat dan pembesaran kedua atrium (gambar 5). Gangguan infiltrasi primer pada miokardium, dicirikan sebagai penggantian otot dengan jaringan fibrosa dan tipe kelainan jaringan lain, dapat menimbulkan RCM. CMR dapat mengidentifikasi jaringan, perubahan anatomi dan dapat menghitung massa miokardium, volume ventrikel dan fraksi ejeksi, sehingga menjadikan CMR modalitas yang baik dalam menilai berbagai variasi $\mathrm{KM}$ infiltratif. Kelainan infiltratif yang sering pada jantung seperti amiloidosis, sarkoidosis, hemokromatosis (atau KM siderotik) dan fibrosis endomiokardium. Perbandingan abnormalitas morfologi dan fungsi KM ini dapat dilihat pada tabel $3 .{ }^{1}$
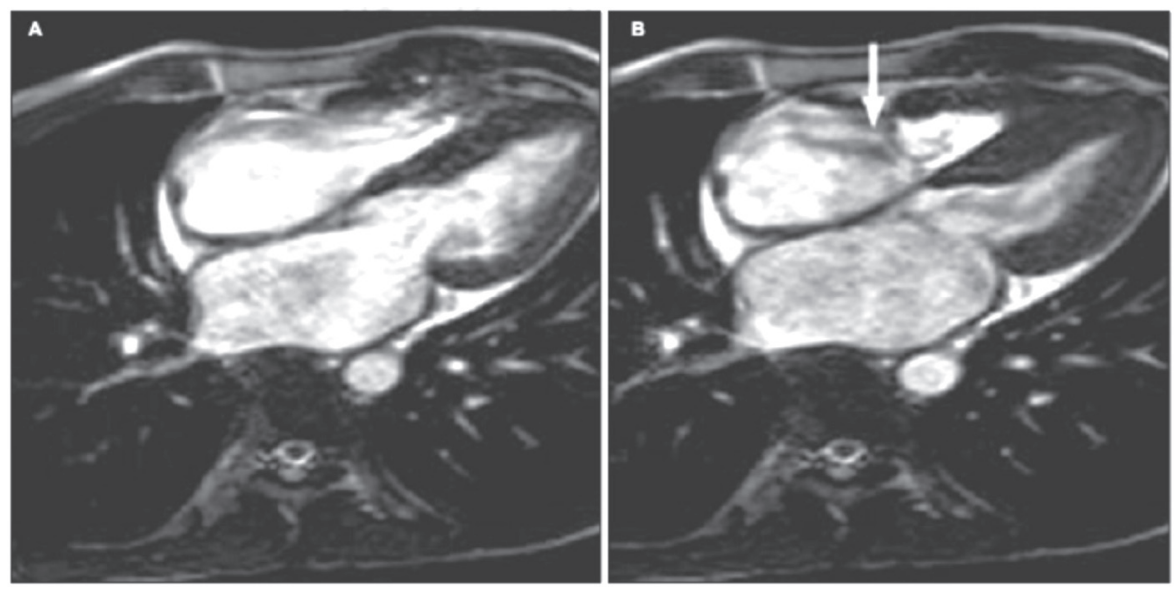

Gambar 5. (A, B) Gambar 4-CH SSFP diastolik (A) menunjukkan ukuran ventrikel normal dengan dilatasi atrium, Gambar sistolik (B) menunjukkan kontraksi sistolik normal dari ventrikel dengan jet regurgitasi trikuspid. (panah). ${ }^{1}$ 
Tabel 3. Abnormalitas morfologi dan fungsi terkait KM. ${ }^{6}$

\begin{tabular}{|c|c|c|c|}
\hline & $\mathrm{DCM}$ & $\mathrm{HCM}$ & RCM \\
\hline \multicolumn{4}{|l|}{ Morfologi } \\
\hline Ukuran ventrikel kiri dan kanan & +++ & - & - \\
\hline Hipertrofi & $+/-$ & +++ & + \\
\hline Dilatasi atrium & ++ & $+/-$ & ++ \\
\hline Efusi pleura & + & - & + \\
\hline Efusi perikard & + & - & + \\
\hline Trombus ventrikel & + & - & - \\
\hline Dilatasi vena kava superior/inferior & + & - & +++ \\
\hline \multicolumn{4}{|l|}{ Fungsi Miokardium } \\
\hline Disfungsi global & +++ & + & + \\
\hline Disfungsi segmental & + & +++ & + \\
\hline Disfungsi diastolik & + & ++ & +++ \\
\hline \multicolumn{4}{|l|}{ Fungsi Katup } \\
\hline Regurgitasi mitral & + & ++ & + \\
\hline Regurgitasi trikuspid & + & - & + \\
\hline
\end{tabular}

\section{Arrhythmogenic Right Ventricular Dysplasia/ARVD}

ARVD merupakan kelainan miokardium dengan etiologi yang belum jelas, ditandai dengan fibrosis pro gresif dan penggantian lemak pada miokardium. Hal ini umumnya terjadi pada dinding anterior ventrikel kanan, yang disebut "triangle of dysplasia" (daerah subtrikuspid, apeks dan infundibulum). ${ }^{2}$ Insiden ARVD sendiri lebih sering pada laki-laki muda dan riwayat pada keluarga. Kondisi ini biasanya menimbulkan kegagalan ventrikel kiri dan dilatasi progresif, serta penyebab penting kematian mendadak pada semua individu dengan usia kurang dari 35 tahun dan 22\% dari kematian mendadak pada atlet muda. ${ }^{13}$

Berdasarkan kriteria task forcetahun 1994 oleh McKenna, dkk, diagnosis ARVD berdasar kriteria mayor dan minor meliputi faktor genetik, elektrokardiografi, patofisiologi dan histopatologi. Kriteria yang tepat untuk ARVD, pasien harus memiliki 2 kriteria mayor, 1 kriteria mayor dan 2 kriteria minor, atau 4 kriteria minor. ${ }^{1}$ Kriteria mayor untuk mendiagnosa ARVD termasuk dilatasi dan reduksi berat fraksi ejeksi RV dengan tanpa ataupun keikutsertaan ringan LV; aneurisma RV terlokalisir (area akinetik atau diskinetik dengan diastolic bulging); dilatasi segmental berat RV. Sedangkan kriteria minor yaitu dilatasi global ringan RV atau penurunan ejeksi fraksi dengan LV yang normal; dilatasi segmental ringan RV; hipokinesia regional RV. Semua kriteria tersebut dapat diperlihatkan dengan menggunakan modalitas CMR.
Modalitas pencitraan tradisional yang digunakan untuk evaluasi abnormalitas ventrikel kanan seperti angiografi konvensional, ekokardiografi dan angiografi nuklir, memiliki sensitifitas dan spesifitas yang rendah, terutama karena ketidakmampuan mengidentifikasi secara akurat abnormalitas struktur dan fungsi ventrikel kanan, serta memliki resolusi spatial yang terbatas dalam mendiagnosa perubahan khas lemak dan lemak-fibrous pad miokardium ventrikel kanan. Biopsi endomiokardium yang sering terjadi kesalahan sampel karena ARVD lebih sering pada dinding anterior, sementara biopsi lebih sering dilakukan pada septum interventrikel. CMR dengan resolusinya yang tinggi, lapangan pandang yang lebar dan kemampuan identifikasi abnormalitas ventrikel kanan, menjadi modalitas pencitraan terpilih untuk pemeriksaan ARVD. ${ }^{1}$

Protokol pencitraan CMR untuk pemeriksaan ARVD adalah sebagai berikut ${ }^{9}$ :

1. Penilaian struktur dan fungsi ventrikel kiri - perlu dipastikan untuk ketebalan potongan 5-6 mm.

a. Analisis RV perlu dilakukan sama hati-hatinya dengan menilai volumetrik LV.

2. Pengambilan gambaran cineSSFP transaksial atau transaksial oblique menutupi ventrikel kanan termasuk RVOT, sehingga gambaran $\mathrm{RV}$ vertical long axis bersama inflow trikuspid direkomendasikan.

3. Sekuen-sekuen pilihan 

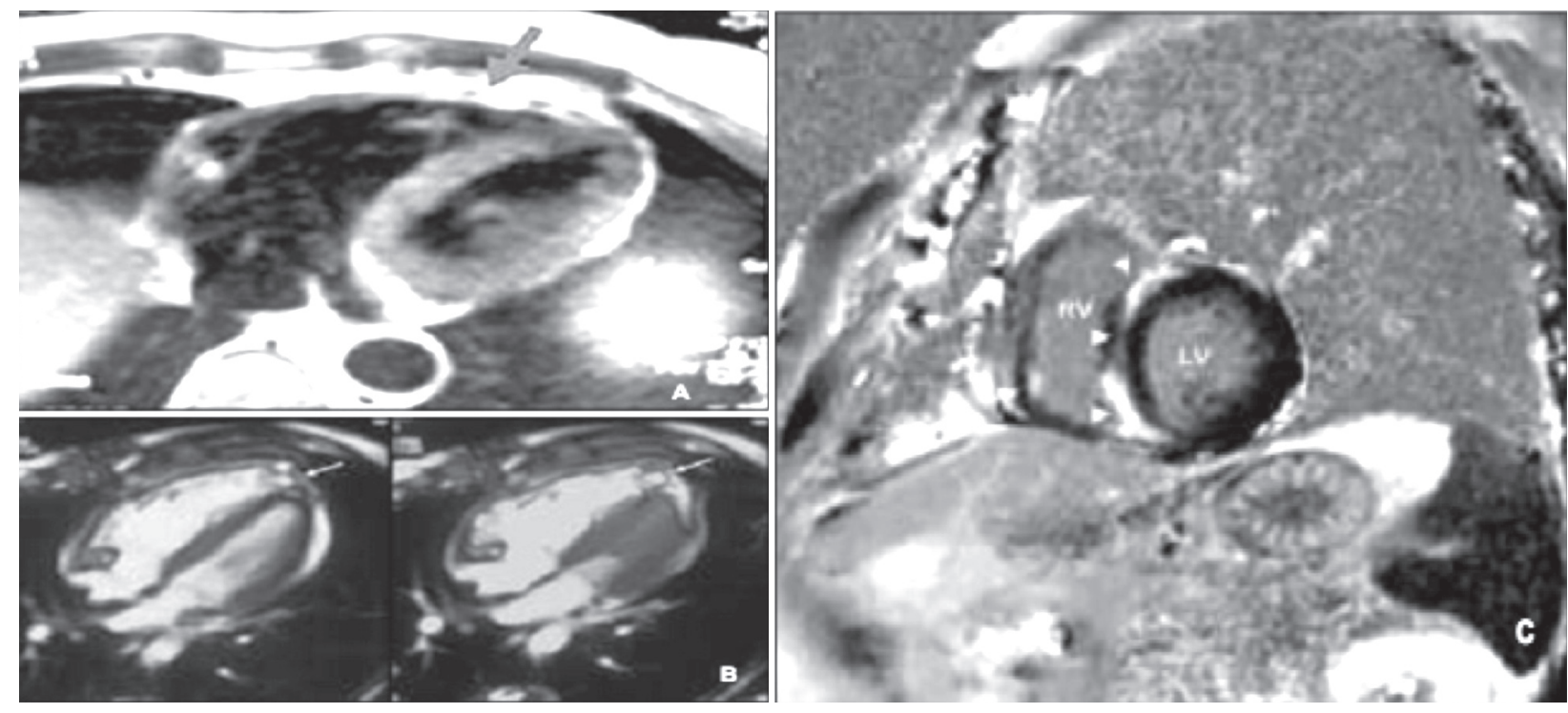

Gambar 6. (A-C) Gambar SE T1W aksial (A) menunjukkan infiltrasi lemak epikardium ke dalam miokardium ventrikel kanan pada dinding anterior (panah). Gambar cine SSFP diastolik dan sistolik (B) menunjukkan daerah diskinetik, mengindikasikan aneurisma pada apeks ventrikel kanan (panah). Gambar DE-CMR aksis pendek (C) menunjukkan berbagai daerah enhancement sepanjang dinding anterior ventrikel kanan (panah) dan septum interventrikuler (panah)Enhancementmemisahkan subendokardium. Biopsi endomiokardium diarahkan di daerah enhance septal yang mengalami penggantian jaringan lemak fibrous. ${ }^{1}$

a. Memilih gambaran black blood transaksial atau transaksial oblique (double inversion recovery T1-weighted fast spin echo).

b. Mengulangi geometri yang sama dengan mensupresi lemak.

c. Late gadolinium enhancement diambil dengan orientasi yang sama seperti di atas, perlu dipastikan T1 nulling untuk RV.

d. Menggunakan permukaan anterior koil hanya untuk meningkatkan resolusi tanpa dipenuhi dengan artefak.

e. Posisi tengkurap pada pasien overweight dapat berguna untuk meminimalisir jarak antara permukaan koil dan RV.

Gambar T1W SE menunjukkan infiltrasi lemak sebagai signal terang dengan penipisan dinding ventrikel kanan dan displasia struktur trabekular. (gambar 6A) Cine-CMR menunjukkan penurunan fungsi global, abnormalitas gerakan dinding regional atau aneurisma (gambar 6B). DE-CMR dapat menunjukkan hyperenhancementpada daerah penggantian lemakfibrous dan mungkin berguna sebagai panduan biopsi endomiokardium (gambar 6C). ${ }^{1}$

CMR dapat secara akurat menghitung lemak intramiokardium, sehingga dapat memonitor perubahan dan proses penyakit. Penting sekali diketahui bahwa infiltrasi lemak terjadi pada $50 \%$ usia tua dengan jantung normal, sementara abnormalitas pergerakan dinding jantung fokal dipertimbangkan sebagai indikator yang lebih diandalkan untuk ARVD dibandingkan adanya lemak intramiokardium yang terisolasi. ${ }^{1}$

\section{Kardiomiopati yang tidak terklasifikasi}

\section{Takotsubo Cardiomyopathy}

Kelainan ini juga disebut "transient apical ballooning syndrome", kondisi ini memiliki karakteristik berupa hiperkontraksi pada basal miokardium dan diskinetik apeks. Pasien dengan kelainan di atas biasanya datang dengan semua manifestasi klinis infark miokardium dengan ST segmen elevasi termasuk nyeri dada, perubahan gambaran elektrokardiogram (EKG) dan peningkatan enzim jantung, namun hasil angiografi koroner normal. Kelainan ini dianggap karena stres terkait peningkatan katekolamin sehingga menyebabkan disfungsi jantung. CMR bermanfaat 
dalam menunjukkan abnormalitas fungsi. Beberapa penelitian dengan CMR menunjukkan kembalinya perubahan pergerakan dinding secara sempurna setelah dievaluasi beberapa minggu kemudian, secara umum tidak ada enhancementyang terlihat pada DECMR. ${ }^{1}$

\section{Ringkasan}

Kardiomiopati adalah suatu kelainan miokardium dimana terdapat abnormalitas struktur dan fungsi otot jantung, tanpa adanya penyakit jantung koroner, hipertensi, penyakit jantung katup dan kongenital. Klasifikasi dan diagnosis didasarkan pada penilaian morfologi dan fungsi jantung. Teknik pencitraan tradisional memiliki keterbatasan dalam menilai dan evaluasi kardiomiopati. CMR menjadi modalitas pencitraan yang paling baik dalam didagnosa dan mencari etiologi kardiomiopati karena memiliki resolusi tinggi serta berbagai teknik pengambilan gambar yang dapat diaplikasikan.

\section{Daftar Pustaka}

1. Jagia P, Gulati G, Sharma S. Cardiac Magnetic Resonance in the Assessment of Cardiomyopathies. Indian J Radiol Imaging. 2007;17:109-19.

2. Elliott P, Andersson B, Arbustini E, Bilinska Z, Cecchi F. Classification of the Cardiomyopathies: a Position Statement From the European Society of Cardiology Working Group on Myocardial and Pericardial Diseases. Eur Heart J. 2008;29:2706.

3. Quarta G, Sado D, Moon J. Cardiomyopathies: Focus on Cardiovascular Magnetic Resonance. The British Journal of Radiology. 2011;84:296-305.
4. O'Hanlon R, Pennell D, Schulz-Menger J, Wabmuth R. Differentiation of Cardiomyopathies by use of CMR. Magnetom Flash. 2007;2:22-33.

5. McCartan C, Mason R, Jayasinghe S, Griffiths L. Cardiomyopathy Classification: Ongoing Debate in the Genomics Era. Biochemistry Research International. 2012:1-10.

6. Mahrholdt H, Wagner A, Judd R, Sechtem U, Kim R. Delayed enhancement cardiovascular magnetic resonance assessment of non-ischaemic cardiomyopathies. Eur Heart J. 2005;26:146174.

7. Park J, Kwon D, Starling R, Marwick T. Role of Imaging in the Detection of Reversible Cardiomyopathy. J Cardiovasc Ultrasound. 2013;21(2):45-55.

8. McMurray J, Adamopoulos S, Anker S, Auricchio A, Bohm M. ESC Guidelines for the diagnosis and treatment of acute and chronic heart failure 2012. Eur Heart J. 2012;33:1787-847.

9. Kramer C, Barkhausen J, Flamm S, Kim R, Nagel E. Standardized Cardiovascular Magnetic Resonance Imaging (CMR) protocols, society for cardiovascular magnetic resonance: board of trustees task force on standardized protocols. Journal of Cardiovascular Magnetic Resonance. 2008 10:35.

10. Gersh B, Phil D, Maron B, Bonow R, Dearani J. ACCF/AHA Guideline for the Diagnosis and Treatment of Hypertrophic Cardiomyopathy. JACC. 2011;58:213-60.

11. Rickers C, Wilke N, Jerosch-Herlod M, Casey S, Panse P. Utility of Cardiac Magnetic Resonance Imaging in the Diagnosis of Hypertrophic Cardiomyopathy. Circulation. 2005;112:85561.

12. Valente A, Lakdawala N, Powell A, Evans S, Cirino A. Comparison of Echocardiographic and Cardiac Magnetic Resonance Imaging in Hypertrophic Cardiomyopathy Sarcomere Mutation Carriers Without Left Ventricular Hypertrophy. Circulation Cardiovascular Genetics. 2013;6:230-7.

13. Ahmad F, Li D, Karibe A, Gonzalez O, Tapscott T, Hill R, et al. Localization of a Gene Responsible for Arrhythmogenic Right Ventricular Dysplasia to Chromosome 3p23. Circulation. 1998;98:2791-5. 